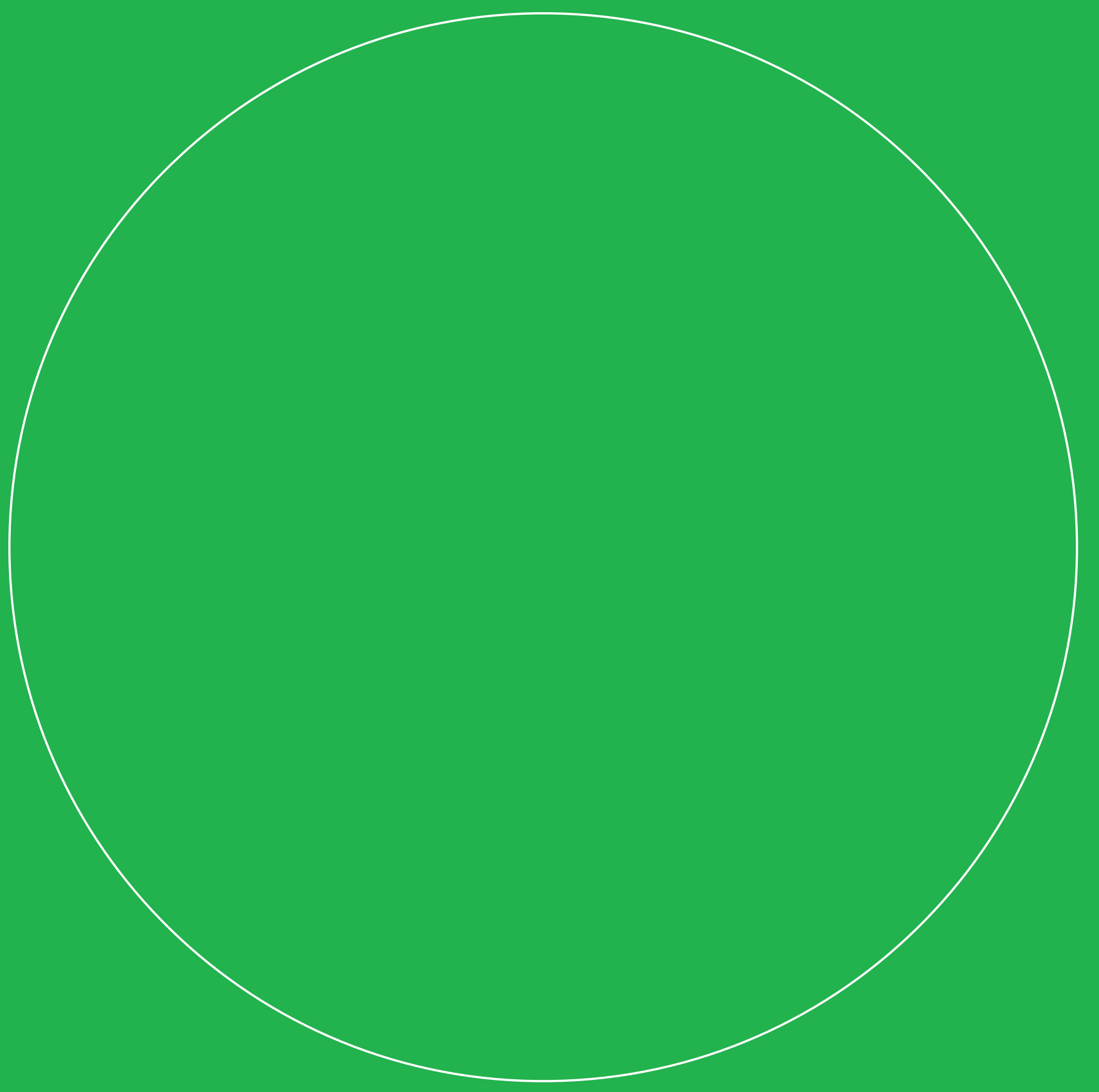

\title{
Inventarisatie van kansrijke Equivalente Maatregelen
}





\title{
Inventarisatie van kansrijke Equivalente Maatregelen
}

\author{
J.J. Schröder
}

Wageningen University \& Research

Dit onderzoek is in opdracht van de Bedrijfsorganisatie Akkerbouw uitgevoerd door de Stichting Wageningen Research (WR), business unit Agrosystems Research, in het kader project 16034.

WR is een onderdeel van Wageningen University \& Research, samenwerkingsverband tussen Wageningen University en de Stichting Wageningen Research.

Wageningen, mei 2017

Rapport WPR-682 
Schröder, J.J, 2017. Inventarisatie van kansrijke Equivalente Maatregelen. Wageningen Research, Rapport WPR-682. 28 blz.; 1 fig.; 10 tab.; 17 ref.

Dit rapport is gratis te downloaden op https://doi.org/10.18174/420238

Telers vinden de huidige gebruiksnormen voor stikstof $(N)$ landbouwkundig in veel gevallen te laag. De overheid nodigt telers uit om maatregelen te nemen die een verhoging van gebruiksnormen rechtvaardigen zonder dat zo'n maatregel tot meer N-uitspoeling en -afspoeling leidt. Gesproken wordt daarom over 'equivalente maatregelen'. Dit rapport analyseert welke maatregelen onder welke voorwaarden aan die definitie van equivalentie kunnen voldoen. Het rapport werkt een aantal maatregelen modelmatig uit voor zover dat niet al elders gebeurde. Het betreft 'verhoging van het aandeel graan', 'afvoer van gewasresten' en 'meer groenbemesters en vanggewassen'. De berekeningen geven aan dat meer graan in een bouwplan een verruiming van de N-gebruiksnorm van enkele kilogrammen $\mathrm{N}$ per hectare bedrijfsoppervlakte kan geven voor iedere 10 procentpunten waarmee het graanaandeel wordt vergroot, tenzij daarbij gebruik gemaakt wordt van de mogelijkheid om, als gevolg van meer graan, ook de N-gebruiksnorm voor extra groenbemesters te innen. De afvoer van gewasresten zoals bietenblad, erwtenloof, preiblad en koolstronken kan de N-gebruiksnorm per hectare bedrijfsoppervlakte met enkele tot tientallen kilogrammen verruimen, afhankelijk van het bouwplan. Als deze gewasresten na bewaring alsnog als organische mest gebruikt worden, doet dit de milieukundige voordelen van de afvoer weer deels teniet. In veel bouwplannen lijkt ruimte te bestaan om na de oogst een onbemest vanggewas te telen. Vanggewassen kunnen in beginsel tot een verruiming van de $\mathrm{N}$-gebruiksruimte leiden. In de onderzochte bouwplannen kon deze verruiming oplopen tot een kleine $10 \mathrm{~kg} \mathrm{~N}$ per hectare bedrijfsoppervlakte. Dit effect vervalt zodra aan de $\mathrm{N}$-onttrekking van de voorgaande hoofdteelt concessies moeten worden gedaan om een succesvolle teelt van een vanggewas überhaupt mogelijk te maken.

Trefwoorden: Nitraatrichtlijn, equivalente maatregel, gebruiksnorm, stikstof

(C) 2017 Wageningen, Stichting Wageningen Research, Wageningen Plant Research, Business unit Agrosystems Research, Postbus 16, 6700 AA Wageningen; T 03174807 00; www.wur.nl/plantresearch

KvK: 09098104 te Arnhem

VAT NL no. 8113.83.696.B07

Stichting Wageningen Research. Alle rechten voorbehouden. Niets uit deze uitgave mag worden verveelvoudigd, opgeslagen in een geautomatiseerd gegevensbestand, of openbaar gemaakt, in enige vorm of op enige wijze, hetzij elektronisch, mechanisch, door fotokopieën, opnamen of enige andere manier zonder voorafgaande schriftelijke toestemming van Stichting Wageningen Research.

Stichting Wageningen Research is niet aansprakelijk voor eventuele schadelijke gevolgen die kunnen ontstaan bij gebruik van gegevens uit deze uitgave.

Rapport WPR-682 


\section{Inhoud}

Woord vooraf $\quad 5$

$\begin{array}{ll}\text { Samenvatting } & 7\end{array}$

1

$\begin{array}{lr}\text { Inleiding } & 9\end{array}$

1.1 Inleiding 9

1.2 Denkbare maatregelen $\quad 11$

1.3 Doel van de onderhavige studie $\quad 12$

2

$\begin{array}{ll}\text { Materialen en methoden } & 13\end{array}$

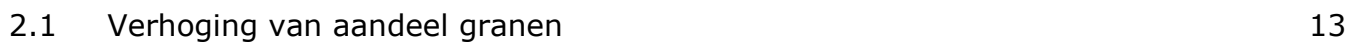

$\begin{array}{ll}2.2 & \text { Afvoer van gewasresten }\end{array}$

2.3 Meer groenbemesters en vanggewassen 14

2.3.1 Achtergrond 14

2.3.2 Methode 15

3

$\begin{array}{ll}\text { Resultaten } & 16\end{array}$

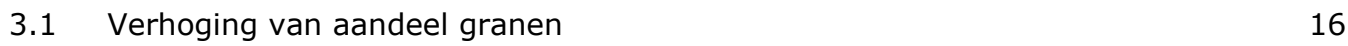

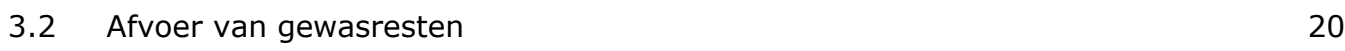

$\begin{array}{lll}3.3 & \text { Meer groenbemesters en vanggewassen } & 21\end{array}$

4

Discussie $\quad 23$

$\begin{array}{ll}\text { Literatuur } & 25\end{array}$ 



\section{Woord vooraf}

Het $5^{\mathrm{e}}$ Nederlandse Actieprogramma EU Nitraatrichtlijn (2014-2017) biedt het landbouwbedrijfsleven de gelegenheid Equivalente Maatregelen te ontwikkelen. Dat zijn maatregelen die onder voorwaarden een verruiming van het gebruik van meststoffen toestaan zonder dat het milieuresultaat verslechtert. De Brancheorganisatie Akkerbouw (BOA) heeft Wageningen UR gevraagd een geactualiseerde inventarisatie van Equivalente Maatregelen te maken en het effect van enkele kandidaat-maatregelen te verkennen. Ik bedank de BOA voor de opdracht hiertoe. Verder ben ik Romke Postma (Nutrient Management Institute) erkentelijk voor het kritisch doornemen van een eerder concept.

Jaap Schröder 


\section{Samenvatting}

Telers vinden de huidige gebruiksnormen voor stikstof $(N)$ landbouwkundig in veel gevallen te laag. De overheid nodigt telers uit om maatregelen te nemen die een verhoging van gebruiksnormen rechtvaardigen zonder dat zo'n maatregel tot meer N-uitspoeling en -afspoeling leidt. Gesproken wordt daarom over 'equivalente maatregelen'. Dit rapport analyseert welke maatregelen onder welke voorwaarden aan die definitie van equivalentie kunnen voldoen. Het rapport werkt een aantal maatregelen modelmatig uit voor zover dat niet al elders gebeurde. Het betreft 'verhoging van het aandeel graan', 'afvoer van gewasresten' en 'meer groenbemesters en vanggewassen'. De berekeningen geven aan dat meer graan in een bouwplan een verruiming van de $\mathrm{N}$-gebruiksnorm van enkele kilogrammen $\mathrm{N}$ per hectare bedrijfsoppervlakte kan geven voor iedere 10 procentpunten waarmee het graanaandeel wordt vergroot, tenzij daarbij gebruik gemaakt wordt van de mogelijkheid om, als gevolg van meer graan, ook de N-gebruiksnorm voor extra groenbemesters te innen. De afvoer van gewasresten zoals bietenblad, erwtenloof, preiblad en koolstronken kan de N-gebruiksnorm per hectare bedrijfsoppervlakte met enkele tot tientallen kilogrammen verruimen, afhankelijk van het bouwplan. Als deze gewasresten na bewaring alsnog als organische mest gebruikt worden, doet dit de milieukundige voordelen van de afvoer weer deels teniet. In veel bouwplannen lijkt ruimte te bestaan om na de oogst een onbemest vanggewas te telen. Vanggewassen kunnen in beginsel tot een verruiming van de $\mathrm{N}$-gebruiksruimte leiden. In de onderzochte bouwplannen kon deze verruiming oplopen tot een kleine $10 \mathrm{~kg} \mathrm{~N}$ per hectare bedrijfsoppervlakte. Dit effect vervalt zodra aan de $\mathrm{N}$-onttrekking van de voorgaande hoofdteelt concessies moeten worden gedaan om een succesvolle teelt van een vanggewas überhaupt mogelijk te maken. 


\section{$1 \quad$ Inleiding}

\subsection{Inleiding}

Om te kunnen voldoen aan kwaliteitsdoelstellingen voor grond- en oppervlaktewater is Nederland in het kader van Europese richtlijnen verplicht om normen vast te stellen voor het gebruik van stikstof$(N)$ en fosfaat- $(P)$ meststoffen. Die normen worden vastgelegd in actieprogramma's. Die zogenaamde gebruiksnormen liggen in een aantal gevallen beneden de hoeveelheden $\mathrm{N}$ en $\mathrm{P}$ die vanuit een landbouwkundig oogpunt als optimaal worden aangemerkt. Dat komt omdat gebruiksnormen, als dat nodig is voor de waterkwaliteit, lager liggen dan wat nodig is voor een optimale gewasopbrengst en/of -kwaliteit. Daar waar de waterkwaliteit niet ter discussie staat, zijn gebruiksnormen gelijk aan het landbouwkundige advies. In de praktijk betekent dit dat gebruiksnormen vooral op zandgrond beneden de landbouwkundige adviezen liggen en dan met name op de zuidelijke zandgronden omdat daar bij zogenaamd uitspoelingsgevoelige gewassen een extra korting op de gebruiksnormen heeft plaatsgevonden. Uitspoelingsgevoelige gewassen zijn gewassen waarbij het N-bodemoverschot bij toepassing van het landbouwkundige advies (op basis van kunstmest- $\mathrm{N}$ ) tot een overschrijding van de waterkwaliteit-norm in het bovenste grondwater leidt.

Het 5e Nederlandse Actieprogramma (2014-2017; Min EZ, 2013) biedt het landbouwbedrijfsleven de gelegenheid om Equivalente Maatregelen te ontwikkelen. Dat zijn maatregelen die alsnog een verruiming van gebruiksnormen kunnen rechtvaardigen. De 'maatregelen' strekken zich uit tot handelingen (bijvoorbeeld een bepaalde wijze van bemesten), het scheppen van omstandigheden (bijvoorbeeld een geringer uitspoelingsrisico) of aantoonbare realisaties (bijvoorbeeld verhoging van de $\mathrm{N}$ - of P-onttrekking door gewassen). Bij dit alles stelt het Actieprogramma als eis dat het milieuresultaat bij toepassing van de Equivalente Maatregel minimaal even goed moet zijn als bij toepassing van de goede landbouwpraktijk waar de gebruiksnormen van uitgaan. De implicatie daarvan is dat toepassing van de Equivalente Maatregel òf het $\mathrm{N}$-bodemoverschot verder moet verlagen dan zou gebeuren bij toepassing van goede landbouwpraktijk, òf moet bewerkstelligen dat een geringer deel van het $\mathrm{N}$-bodemoverschot uiteindelijk in het grond- of oppervlaktewater terechtkomt. Het bodemoverschot wordt daarbij gedefinieerd als het verschil tussen de aangevoerde hoeveelheid $\mathrm{N}$ (meststoffen, depositie, zaad en pootgoed, biologische $\mathrm{N}$ fixatie) enerzijds en de hoeveelheid afgevoerde $\mathrm{N}$ in oogstproducten en als ammoniak vervluchtigde $\mathrm{N}$ anderzijds. Omdat het beleidsmatig niet de bedoeling is om de emissie van ammoniak te verhogen en het vanuit ondernemers bezien niet gewenst is om de $\mathrm{N}$-aanvoer te verlagen, komen Equivalente Maatregelen die gericht zijn op het verlagen van het bodemoverschot feitelijk neer op het verhogen van onttrekkingen. De andere optie, waarbij een geringer deel van het bodemoverschot in het grond- of oppervlaktewater terechtkomt, kan alleen worden gerealiseerd via het tegengaan van oppervlakkige afspoeling, het verhogen van de $\mathrm{N}$-voorraad in de bodem en/of het verhogen van denitrificatie. Dit laatste komt neer op het verlagen van de ratio van de uit- of afspoelfractie (hoeveelheid uit- of afgespoelde $\mathrm{N}$ per eenheid bodemoverschot) en het neerslagoverschot. In formulevorm:

$\mathrm{N}$-concentratie in grond- of oppervlaktewater $=$ (aanvoer - gewasonttrekking - ammoniakverlies $) \mathrm{x}$ (uit- of afspoelfractie) / neerslagoverschot

Het $5^{\mathrm{e}}$ Actieprogramma stelt als eis dat een Equivalente Maatregel vooraf onderbouwd moet kunnen worden of achteraf gemonitord, geborgd kan worden en geen onaanvaardbare vergroting van de uitvoerings- of handhavingslast met zich meebrengt. Niet als zodanig omschreven maar wel logisch is verder de eis dat een Equivalente Maatregel niet mag leiden tot afwentelingen van de uit- en afspoeling naar andere plaatsen of tijdstippen.

Voor zover Equivalente Maatregelen stoelen op een verlaging van het bodemoverschot moet aannemelijk gemaakt worden dat de maatregel (handeling, omstandigheid, realisatie) leidt tot een hogere onttrekking. Als de maatregel beoogt om de aangeboden meststoffen beter opneembaar te 
maken voor een gewas door een betere timing of plaatsing ten opzichte van de gebruikelijke timing of plaatsing, zal dit alleen dan tot een hogere onttrekking en lagere bodemoverschot leiden als het desbetreffende gewas suboptimaal bemest wordt (Figuur 1). Dat betekent niet dat die betere timing of plaatsing in alle anders situaties geen nut heeft. Het betekent immers dat in die situaties in het desbetreffende gewas nutriënten bespaard kunnen worden die vervolgens ingezet kunnen worden op een perceel of in een gewas waar de teler tekort denkt te komen. In dat geval is de maatregel dus wel zinnig maar rechtvaardigt geen verruiming van de gebruiksruimte. Volstaan kan dan worden met een verschuiving van eenzelfde inzet van nutriënten binnen een bedrijf, een optie die ook nu al gebruikt kan worden. In dat geval kan niet gesproken worden van een Equivalente Maatregel.

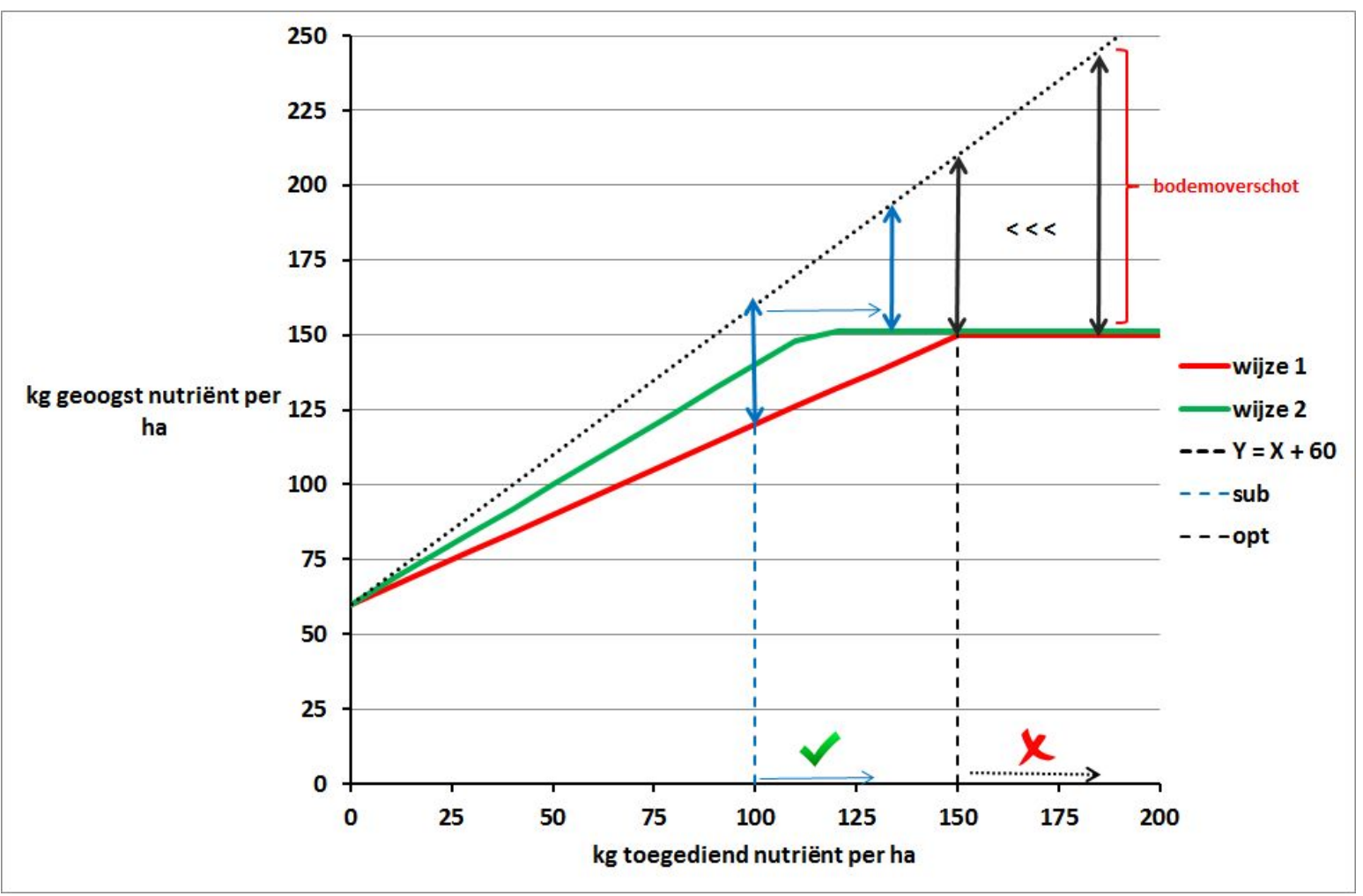

Figuur 1 Wijzigingen van het bodemoverschot (het verschil tussen aanbod en onttrekking, weergegeven met verticale pijlen) in afhankelijkheid van het al dan niet onttrekkings-beperkend zijn van de nutriënten-gebruiksruimte: bij suboptimale gebruiksnorm (blauwe onderbroken streepjeslijn: gebruiksnorm < landbouwkundige advies) leidt een efficiëntere wijze van bemesting (groene respons (wijze 2) ten opzichte van rode respons (wijze 1)) tot een hogere onttrekking en een lager bodemoverschot en, bijgevolg, ruimte voor hogere gift (blauwe pijlen); bij een optimale gebruiksnorm (zwarte onderbroken streepjeslijn: gebruiksnorm = landbouwkundig advies) niet.

Bij de vaststelling van gebruiksnormen is in beperkte mate rekening gehouden met verschillen tussen grondsoorten, gewassen, teeltwijzen en rassen (Min EZ, 2013). Binnen die groepen wordt echter uitgegaan van gemiddelde omstandigheden qua bodem en management. Dat betekent globaal dat in een aantal gevallen meer nutriënten toegediend mogen worden dan vanuit een waterkwaliteitsoogpunt eigenlijk wenselijk is, net zoals in een aantal andere gevallen gewassen vanuit datzelfde waterkwaliteitsoogpunt onnodig tekort gedaan wordt. Zo staan tegenover percelen, bedrijven en arealen met boven-gemiddelde onttrekkingen, per definitie, 'evenveel' percelen, bedrijven en arealen met beneden-gemiddelde onttrekkingen. Omdat al die bedrijven met dezelfde gebruiksnorm werken, betekent dat dat de waterkwaliteit op eerstgenoemde bedrijven in principe hoger is dan een beoogd niveau en op laatstgenoemde bedrijven in principe lager is dan dat beoogde niveau. Vanuit de definitie van Equivalente Maatregelen is het voorstelbaar dat bedrijven met een bovengemiddelde onttrekking meer gebruiksruimte krijgen. Dat betekent dat daar de aanvankelijk onnodig goede waterkwaliteit iets minder 'goed' zal worden en de gemiddelde waterkwaliteit van de populatie bedrijven als geheel daarmee stijgt en boven de norm terecht kan komen. Dit is alleen te corrigeren als een verruiming 
van de gebruiksnorm op bedrijven met boven-gemiddelde onttrekkingen hand in hand gaan met een verlaging van de gebruiksnorm op bedrijven met beneden-gemiddelde onttrekkingen. Pas als een bedrijf (of groep van bedrijven) zijn onttrekking weet te verhogen (lees: bodemoverschot weet te verlagen) ten opzichte van zijn eigen prestaties in het verleden, rechtvaardigt dat een verruiming van gebruiksnormen zonder verlaging van gebruiksnormen elders. Dat vereist wel, zoals hiervoor aangegeven, dat ondubbelzinnig moet kunnen vastgesteld wat de huidige onttrekkingen zijn geworden en de toenmalige onttrekkingen waren.

\subsection{Denkbare maatregelen}

Zoals hierboven aangegeven zijn denkbare effectieve equivalente maatregelen in te delen in maatregelen die het bodemoverschot verlagen en maatregelen die een geringer deel van het bodemoverschot doen uit- of afspoelen.

Tot de eerste groep maatregelen behoren:

A1. Verhoging van de afvoer door hogere opbrengsten van het hoofdproduct,

A2. Verhoging van de afvoer door afvoer van gewasresten,

A3. Verlaging van het bedrijfsgemiddelde bodemoverschot door een groter aandeel gewassen met een laag bodemoverschot ten koste van het aandeel gewassen met een hoog bodemoverschot,

A4. Verhoging van de afvoer door rijenbemesting,

A5. De inzet van groenbemesters en vanggewassen,

A6. Het gebruik van beter opneembare meststoffen,

A7. Verhoging van de afvoer door geleide bemesting.

Tot de tweede groep van maatregelen behoren:

B1. Gebruik van onbemeste, begroeide bufferstroken,

B2. Afdamming van greppels,

B3. Bevorderen van denitrificatie door peilverhoging,

B4. Bevorderen van denitrificatie door tijdelijke inundatie,

B5. Bevorderen van denitrificatie buiten het groeiseizoen door toediening van een substraat at gemakkelijk afbreekbare koolstof bevat.

Tot slot is er nog een groep van maatregelen die in theorie kunnen werken via een verlaging van het bodemoverschot (door het verhogen van de afvoer) maar daarop een relatief onzeker effect hebben. Vanwege die onzekerheid kan hun uiteindelijke invloed op emissies beter worden geborgd door hun effect op de afvoer te bepalen, dan door de inzet van die maatregel zelf als equivalente maatregel aan te merken. Voorbeelden daarvan zijn:

C1. Het gebruik van beregening,

C2. Het gebruik van vaste rijpaden,

C3. Het beperken van kerende grondbewerkingen,

C4. Het bevorderen van de bodemkwaliteit.

In alle gevallen leiden alle maatregelen vanzelfsprekend alleen dan tot een verminderde uit- of afspoeling als het nemen van de maatregel een wijziging inhoudt ten opzichte van een referentiesituatie (gevormd door handelingen, omstandigheden of realisaties in het verleden, waarvan uitgegaan is bij het vaststellen van gebruiksnormen).

In het kader van dit rapport wordt verder niet ingegaan op maatregelen van het type A1 ('opbrengstverhoging'). Deze zijn uitgebreid gerapporteerd in Schröder \& De Haan (2015), Schröder et al. (2015ab), Schröder (2016) en Schröder \& Van Dijk (2017). Dat geldt ook voor maatregelen van het type A4 ('rijenbemesting'). Het effect daarvan op gebruiksnormen wordt beschreven in Schröder et al. (2015a). Dat geldt ook voor maatregelen van het type A6 ('beter opneembare meststoffen'). Daarover kan nog het volgende worden opgemerkt. Eén van de redenen waarom aan organische meststoffen een werkingscoëfficiënt lager dan $100 \%$ wordt toegekend is het feit dat een deel van de nutriënten vrijkomt buiten de periode waarin gewassen deze kunnen opnemen. Als gevolg hiervan is het bodemoverschot groter bij gebruik van organische mest dan bij het gebruik van kunstmest. Bij het 
vaststellen van de gebruiksnormen is, overeenkomstig de praktijk, uitgegaan van het gebruik van organische mest. Dat impliceert dat bij het niet-gebruik van organische mest (of het gebruik van organische meststoffen met een laag aandeel organisch gebonden nutriënten) een verruiming van gebruiksnormen zou kunnen plaatsvinden omdat het bodemoverschot dan lager is. Het effect van deze 'equivalente maatregel' is reeds gerapporteerd in Schröder \& De Haan (2015), Schröder et al. (2015a) en Schröder (2016). Genoemde bronnen gaan niet in op verschillen in opneembaarheid van bepaalde kunstmeststoffen. In proeven en praktijk wordt doorgaans gebruik gemaakt van kalkammonsalpeter (KAS), een meststof waarvan de $\mathrm{N}$ voor $50 \%$ uit ammonium- $\mathrm{N}$ en voor $50 \%$ uit nitraat- $\mathrm{N}$ bestaat. Ammonium-N is minder uitspoelingsgevoelig dan nitraat- $N$. Daarom is het in beginsel voorstelbaar dat meststoffen die volledig uit ammonium bestaan en waarbij die ammonium bovendien tegen een snelle omzetting in nitraat beschermd wordt door nitrificatieremmers, beter beschikbaar is voor gewassen. Onderzoek daarnaar geeft vooralsnog aan dat dat met name een rol kan spelen bij (te) vroege toediening van $\mathrm{N}$ op gewassen die vroeg in het voorjaar hun groei hernemen zoals grasland en wintergranen. Voor zover bekend is er bij akker- en tuinbouwgewassen waarvan de N-benutting soms te wensen overlaat (en dat zijn juist niet de 'vroeg aanwezige' wintergranen) onvoldoende onderzoek geweest om te kunnen beoordelen of het gebruik van andere soorten kunstmest als equivalente maatregel kan worden aangemerkt. Voor wat betreft maatregelen van het type A7 ('geleide bemesting') wordt verwezen naar de rapportage van De Ruijter et al. (2017) die dit voor aardappelen onderzochten.

Daarmee resteren maatregelen van het type A2 ('afvoer van gewasresten'), type A3 ('verhogen van het aandeel gewassen met laag bodemoverschot') en type A5 ('groenbemesters en vanggewassen'). De effecten van die maatregelen worden in het navolgende verkend.

Voor wat betreft maatregelen van het type B1 tot en met B4 wordt verwezen naar uitgebreide literatuur op dit soort waterbeheer-gerelateerde maatregelen (Os, van et al., 2009; Stuyt et al., 2009; Noij et al., 2008 \& 2009; Schoumans et al., 2012; Groenendijk et al., 2016). Voor een evaluatie van het effect van maatregelen van het type B5 ('bevorderen van denitrificatie buiten het groeiseizoen door toediening van een substraat') is het nog te vroeg. Op dit moment vinden er analyses plaats van meerjarige datasets waarmee de hypothese getoetst kan worden of uitspoeling kan worden verminderd door het aanbieden van gemakkelijk afbreekbare koolstofverbindingen. Dit soort analyses zijn lastig omdat dat aanbod vaak verstrengeld is met andere factoren die ook van invloed kunnen zijn op de uitspoeling.

\subsection{Doel van de onderhavige studie}

In aanvulling op de hiervoor beschreven definitie van equivalente maatregelen en de voorwaarden voor hun toepassing (paragraaf 1.1) en de, op grond daarvan, opgestelde longlist van kandiderende maatregelen (paragraaf 1.2), geeft dit rapport ook een becijfering van:

- de afvoer van gewasresten,

- verhogen van het aandeel gewassen met een laag N-bodemoverschot,

- verhoging van het aandeel groenbemesters en vanggewassen. 


\section{$2 \quad$ Materialen en methoden}

\subsection{Verhoging van aandeel granen}

Granen staan te boek als gewassen die N efficiënt uit de bodem kunnen opnemen en daarom gepaard kunnen gaan met een relatief laag $\mathrm{N}$-bodemoverschot. Dit in tegenstelling tot gewassen zoals aardappelen, suikerbieten en veel bladgroenten. Vanuit die optiek is berekend hoe het $\mathrm{N}$-bodemoverschot en de $\mathrm{N}$-uitspoeling veranderen als het graanaandeel met stapjes van $10 \%$ wordt verhoogd waarbij deze verhoging, naar rato, ten koste gaat van alle overige gewassen in het bouwplan. Deze berekening is uitgevoerd voor drie grondsoort-gewas combinaties: noordelijke klei, noordelijk zand en zuidelijk zand. Daarbij is steeds aangenomen dat $\mathrm{P}$ werd toegediend volgens de gebruiksnorm bij de toestand 'neutraal' ( $60 \mathrm{~kg} \mathrm{P}_{2} \mathrm{O}_{5}$ per jaar) in de vorm van rundveedrijfmest en kunstmest- $\mathrm{N}$ werd aangevuld tot de $\mathrm{N}$-gebruiksnorm. Verder is aangenomen dat het graanstro is afgevoerd en zijn varianten vergeleken waarbij na de oogst van het graan wel of geen groenbemester wordt verbouwd waaraan de wettelijk toegestane $\mathrm{N}$-gebruiksnorm (50 en $60 \mathrm{~kg} \mathrm{~N}$ per hectare op, respectievelijk, zandgrond en kleigrond) al dan niet kan worden toegediend. Verdere uitgangspunten van de genoemde grondsoort-gewascombinaties worden gegeven in Tabel 1a-1c.

Tabel 1a Gewasaandelen en opbrengstniveaus (ton vers/ha) van de onderzochte combinaties op de noordelijke kleigrond.

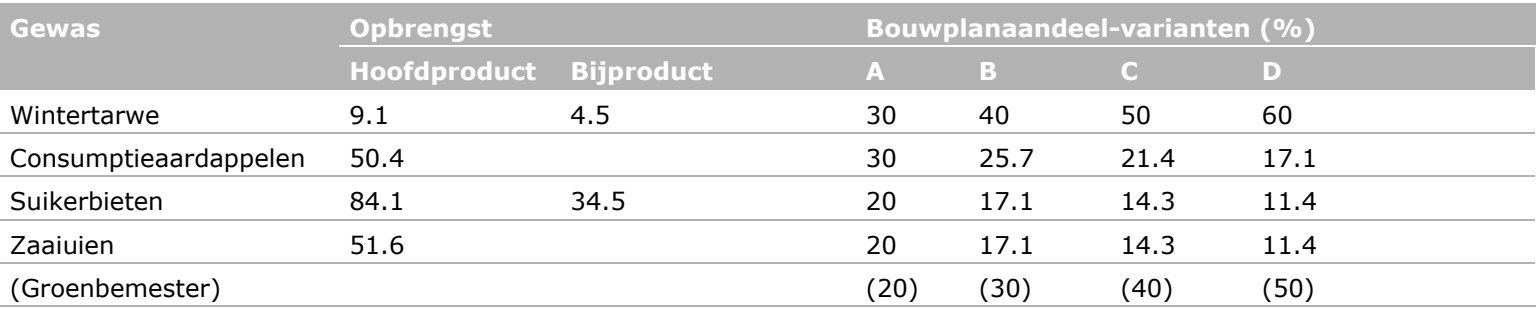

Tabel $1 \boldsymbol{b}$ Gewasaandelen en opbrengstniveaus (ton vers/ha) van de onderzochte combinaties op de noordelijke zand- en dalgrond.

\begin{tabular}{llllllll} 
& Opbrengst & & \multicolumn{3}{c}{ Bouwplanaandeel-varianten (\%) } \\
\cline { 2 - 8 } & Hoofdproduct & Bijproduct & A & B & \multicolumn{2}{c}{ C } & D \\
Zomergerst & 6.4 & 3.5 & 35 & 45 & 55 & 65 & 75 \\
\hline Zetmeelaardappelen & 41.5 & & 50 & 42.3 & 34.6 & 26.9 & 19.2 \\
\hline Suikerbieten & 76.2 & 34.5 & 15 & 12.7 & 10.4 & 8.1 & 5.8 \\
\hline (Groenbemester) & & & $(35)$ & $(45)$ & $(55)$ & $(65)$ & $(75)$
\end{tabular}

Tabel 1c Gewasaandelen en opbrengstniveaus (ton vers/ha) van de onderzochte combinaties op de zuidelijke zandgrond.

\begin{tabular}{|c|c|c|c|c|c|c|}
\hline \multirow[t]{2}{*}{ Gewas } & \multicolumn{2}{|l|}{ Opbrengst } & \multicolumn{4}{|c|}{ Bouwplanaandeel-varianten $(\%)$} \\
\hline & Hoofdproduct & Bijproduct & A & B & C & D \\
\hline Zomergerst & 6.4 & 3.5 & 30 & 40 & 50 & 60 \\
\hline Suikerbieten & 76.2 & 34.5 & 15 & 12.9 & 10.7 & 8.6 \\
\hline Snijmaïs & 46.1 & & 25 & 21.4 & 17.9 & 14.3 \\
\hline
\end{tabular}


De berekeningen zijn verricht met het WOG 2.0 model (Schröder et al., 2015) in combinatie met geactualiseerde opbrengstgegevens en uitspoelingsfactoren (Groenendijk et al., 2014; Schröder, 2016). Dat model berekent de $\mathrm{N}$-afvoer als het product van de opgegeven opbrengsten (Tabel 1a-1c) en gewasspecifieke $\mathrm{N}$-gehalten (Van Dijk, 2003) en de $\mathrm{N}$-aanvoer volgens opgegeven giften aan $\mathrm{N}$ in de vorm organische mest (hier rundveedrijfmest, www.bemestingsadvies.nl), kunstmest (gebruiksnorm minus werkzame $\mathrm{N}$ uit organische mest), depositie en eventuele biologische $\mathrm{N}$-binding. De opgegeven opbrengsten zijn gebaseerd op recente KWIN cijfers. Deze cijfers hebben vanzelfsprekend betrekking op 'normale' bouwplannen en rotaties. Het is voorstelbaar dat opbrengsten iets anders reageren op sterk afwijkende bouwplannen vanwege rotatie-effecten maar hieraan wordt gemakshalve voorbij gegaan.

\subsection{Afvoer van gewasresten}

Ook gewasresten bevatten $\mathrm{N}$ en $\mathrm{P}$. Door gewasresten niet op het land achter te laten maar te verwijderen, kan het bodemoverschot verlaagd worden en, in verband daarmee, de uitspoeling van $\mathrm{N}$. Het effect hiervan is berekend voor een viertal bouwplannen, karakteristiek voor de zandgronden (bouwplan A Noordelijke Zandgrond, bouwplannen B-D voor Zuidelijke Zandgrond), met een aanmerkelijk aandeel gewassen met relatief $\mathrm{N}$-rijke gewasresten. Daarbij is steeds aangenomen dat $\mathrm{P}$

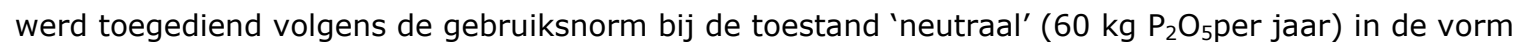
van rundveedrijfmest en kunstmest- $\mathrm{N}$ werd aangevuld tot de $\mathrm{N}$-gebruiksnorm. Aangenomen is dat geen groenbemesters worden geteeld. Verdere uitgangspunten worden gegeven in Tabel 1d.

Tabel 1d Bouwplansamenstellingen, opbrengstniveaus (ton vers/ha) en $\mathrm{N}$-inhoud van gewasrest ( $k g \mathrm{~N} / \mathrm{ha}$ ) van de onderzochte varianten met en zonder afvoer bij gewasresten.

\begin{tabular}{|c|c|c|c|c|c|c|c|}
\hline \multirow[t]{2}{*}{ Gewas } & \multicolumn{2}{|l|}{ Opbrengst } & \multirow{2}{*}{$\begin{array}{l}\mathbf{N} \text { in } \\
\text { gewasrest }\end{array}$} & \multicolumn{2}{|c|}{ Bouwplansamenstellling } & \multirow[b]{2}{*}{ C } & \multirow[b]{2}{*}{ D } \\
\hline & Hoofdproduct & Bijproduct & & $\mathbf{A}$ & B & & \\
\hline Zomergerst & 6.4 & 3.5 & 19 & 33.3 & & & \\
\hline Suikerbiet & 76.2 & 34.5 & 117 & 16.7 & 12.5 & & \\
\hline Doperwten & 6.9 & 20 & 82 & & 12.5 & & \\
\hline Snijmaïs & 46.1 & & & & 25 & & \\
\hline Waspeen & 68.8 & & & & 12.5 & & \\
\hline Broccoli* & 13.5 & 26 & 88 & & & & 50 \\
\hline Groenbemester & & & & 0 & 0 & 0 & 0 \\
\hline
\end{tabular}

*onder verrekening van het feit dat in $30 \%$ van de gevallen een tweede teelt volgt

\subsection{Meer groenbemesters en vanggewassen}

\subsubsection{Achtergrond}

Groenbemesters en vanggewassen kunnen via een verbeterde voorziening met $\mathrm{N}$ of via een verbeterde opneembaarheid van $\mathrm{N}$ tot een hogere opbrengst en $\mathrm{N}$-afvoer door volgteelten leiden. Bezien vanuit $\mathrm{N}$-uitspoelingsrisico's moet die potentiële verhoging van de $\mathrm{N}$-afvoer wel worden afgewogen tegen de extra $\mathrm{N}$-bemesting die aan de groenbemesters (niet aan vanggewassen) zélf gegeven mag worden. Zo wordt het netto-effect op het bodemoverschot bepaald. De $\mathrm{N}$-gebruiksnormen voor groenbemesters bedragen 50 en $60 \mathrm{~kg}$ werkzame $\mathrm{N}$ per hectare op, 
respectievelijk, zandgronden (inclusief lössgronden) en kleigronden. Als die bemesting, gemiddeld over het bedrijf, hoger is dan de gemiddeld gerealiseerde extra $\mathrm{N}$-afvoer ten opzichte van een situatie zonder groenbemester, neemt het $\mathrm{N}$-bodemoverschot dus toe en daarmee ook de $\mathrm{N}$-uitspoeling. Als een bedrijf op zandgrond eens per vier jaar een groenbemester teelt en gebruik maakt van de $\mathrm{N}$-gebruiksnorm die aan groenbemesters is toegekend ( $50 \mathrm{~kg} \mathrm{~N} / \mathrm{ha}$ ), moet de gemiddeld gerealiseerde extra $\mathrm{N}$-afvoer dus 50/4 = 12,5 kg N per hectare bedragen. Dat komt overeen met een meeropbrengst (in de vorm van $\mathrm{N}$ ) van circa $10 \%$ en dat is ambitieus.

Dit dilemma speelt niet bij vanggewassen die het zonder extra bemesting moeten stellen met de restanten aan bodem-N die na de oogst achterblijven. Ook voor dit soort gewassen geldt echter dat ze alleen dan tot extra $\mathrm{N}$-afvoer, een kleiner $\mathrm{N}$-bodemoverschot en minder $\mathrm{N}$-uitspoeling zullen leiden in situaties waar de $\mathrm{N}$-afvoer van volgteelten door een krappe $\mathrm{N}$-bemesting positief reageert op een extra $\mathrm{N}$-aanbod vanuit het ingewerkte vanggewas. Ook als de extra $\mathrm{N}$-levering vanuit de groenbemester wordt gecompenseerd door een lagere $\mathrm{N}$-gift, neemt het bodemoverschot af. Maar die situatie wordt hier niet beschouwd omdat verlaging van $\mathrm{N}$-giften nu juist niet het motief voor equivalente maatregelen is (zie paragraaf 1.1).

Verhoeven et al. (2011) verkenden de mogelijkheden voor een succesvolle teelt van vanggewassen na consumptieaardappelen en snijmaïs. Zij concludeerden dat vanggewassen het N-bodemoverschot (en bijgevolg de uitspoeling van $\mathrm{N}$ ) alleen dan verlagen en aldus een verruiming van het gebruik van $\mathrm{N}$ toelaten, in $\mathrm{N}$-responsieve situaties. Dat komt er op neer dat positieve effecten alleen daar verwacht mogen worden waar de $\mathrm{N}$-gebruiksnormen voor met name uitspoelingsgevoelige gewassen op een lager niveau zijn vastgesteld dan de geadviseerde N-bemestingsrichtlijnen. Dit geldt voor de zand- en lössgronden in Zuid Nederland. Uit de genoemde studie blijkt ook dat vanggewassen alleen dan een betekenisvolle bijdrage aan het onderscheppen van $\mathrm{N}$ leveren als ze voldoende groeikansen krijgen. Dat geldt evenzeer voor ondergezaaide vanggewassen als voor vanggewassen die in de stoppel gezaaid worden. Omwille van die groeikansen zijn bij snijmaïs en aardappelen concessies nodig aan de oogstdatum. Als gevolg daarvan moet voor zeer vroege rassen gekozen worden waarvan de opbrengst en N-onttrekking doorgaans iets lager is. Per saldo betekent dit dat het bodemoverschot-verlagende effect van de teelt van een vanggewas enigszins teniet gedaan wordt door het bodemoverschotverhogende effect van een vroeger geoogst voorafgaand hoofdgewas (Verhoeven et al., 2011).

\subsubsection{Methode}

Het effect van de teelt van meer vanggewassen is verkend voor de bouwplannen zoals genoemd in Tabel 1d. Daarbij is aangenomen dat in bouwplan A na de teelt van zomergerst en zetmeelaardappelen (83,3\% van het bedrijfsareaal) alsnog een vanggewas verbouwd kan worden. Voor bouwplan B is dit na de teelt van consumptieaardappelen, conservenerwt en waspeen ( $50 \%$ van het bedrijfsareaal), voor bouwplan $C$ is dit na de teelt van prei en ijssla ( $100 \%$ van bedrijfsareaal) en voor bouwplan $\mathrm{D}$ is dit na de teelt van prei en broccoli ( $100 \%$ van het bedrijfsareaal). Omdat niet uit te sluiten valt dat een vanggewas na bepaalde hoofdgewassen alleen succesvol geteeld kan worden door de $\mathrm{N}$-opnameperiode van dat hoofdgewas enigszins in te korten, is in de berekeningen ook een variant opgenomen waarbij de $\mathrm{N}$-onttrekking van zetmeelaardappelen, consumptieaardappelen, prei, ijssla en broccoli $10 \%$ gereduceerd is. Aangenomen is dat een onbemest vanggewas gemiddeld $40 \mathrm{~kg}$ $\mathrm{N}$ per hectare opneemt en dat daarvan $60 \%$ vrijkomt tijdens een voor hoofdgewassen relevante periode (Verhoeven et al., 2011), dat wil zeggen een periode waarin dat hoofdgewas positief op $\mathrm{N}$ kan reageren. Hoewel in bouwplan $\mathrm{B}$ ook snijmaïs opgenomen is waarna de teelt van een vanggewas mogelijk is, is dit gewas in eerste instantie buiten de berekening gehouden omdat de teelt van een vanggewas op zand- en lössgrond al verplicht is en niets wijzigt aan N-gebruiksnormen omdat met die verplichting al rekening is gehouden bij besluitvorming over de huidige $\mathrm{N}$-gebruiksnorm voor snijmaïs. Omdat voor dit gewas de relaties tussen de oogsttijd en $\mathrm{N}$-onttrekking enerzijds en oogsttijd en groeikansen voor vanggewassen anderzijds, al cijfermatig onderbouwd is, kan hiermee wel geïllustreerd worden hoe bodemoverschot-verlagende en bodemoverschot verhogende effecten elkaar kunnen tegenwerken. 


\section{Resultaten}

\subsection{Verhoging van aandeel granen}

De mate waarin een verhoging van het aandeel granen een verlagend effect heeft op de $\mathrm{N}$-concentratie van het ontvangende grond- of oppervlaktewater hangt van het antwoord op de vraag of, als gevolg van die verhoging, de gemiddelde $\mathrm{N}$-gebruiksnorm op bedrijfsniveau minder sterk toeneemt dan de gemiddelde $\mathrm{N}$-onttrekking op bedrijfsniveau (dan wel of de gemiddelde $\mathrm{N}$ gebruiksnorm sterker afneemt dan de gemiddelde $\mathrm{N}$-onttrekking). Als de teelt van graan niet gevolgd wordt door een groenbemester waarvoor de toegestane $\mathrm{N}$-gebruiksnorm verzilverd wordt, leidt meer graan tot een lagere $\mathrm{N}$-concentratie in het ontvangende water in alle drie de onderzochte regio's (Tabel 2a-2c). Als graan wel gevolgd wordt door een bemeste groenbemester, neemt het bodemoverschot en de berekende $\mathrm{N}$-concentratie op kleigrond (Tabel 2a) en ook op de Zuidelijke Zandgrond (Tabel $2 \mathrm{c}$ ) echter toe met een toename van het graanaandeel. Alleen op de Noordelijke Zandgrond neemt de berekende $\mathrm{N}$-concentratie met een toename van het graanaandeel, ondanks de toename van het aandeel bemeste groenbemesters, af (Tabel 2b). Kennelijk is het effect sterk afhankelijk van de samenstelling van het overige bouwplan en de daaraan toegekende $\mathrm{N}$-gebruiksnormen en zijn categorische uitspraken niet mogelijk zodra bemeste groenbemesters na graan geteeld worden. Een nadere analyse van de bouwplansamenstelling die het effect op de $\mathrm{N}$-concentratie positief of negatief laat zijn, valt buiten het bestek van deze beperkte studie.

Als de teelt van (meer) graan niet gepaard gaat met de teelt van een groenbemester die gebruik maakt van de daaraan toegekende $\mathrm{N}$-gebruiksnorm, zou volgens berekening 1 tot $4 \mathrm{~kg}$ meer $\mathrm{N}$ per hectare bedrijfsoppervlakte gebruikt mogen worden (dan thans voor dat specifieke bouwplan toegestaan is) voor iedere 10 procentpunten meer graan. 
Tabel 2a Kleigrond: effect van hoger graanaandeel op N-gebruiksnorm, $N$-onttrekking, $N$ bodemoverschot, $\mathrm{NO}_{3}$-concentratie van drain- en slootwater ( $\mathrm{mg} \mathrm{NO}_{3}$ per liter) en de extra of verminderde $\mathrm{N}$-ruimte in functie van het aandeel graan.

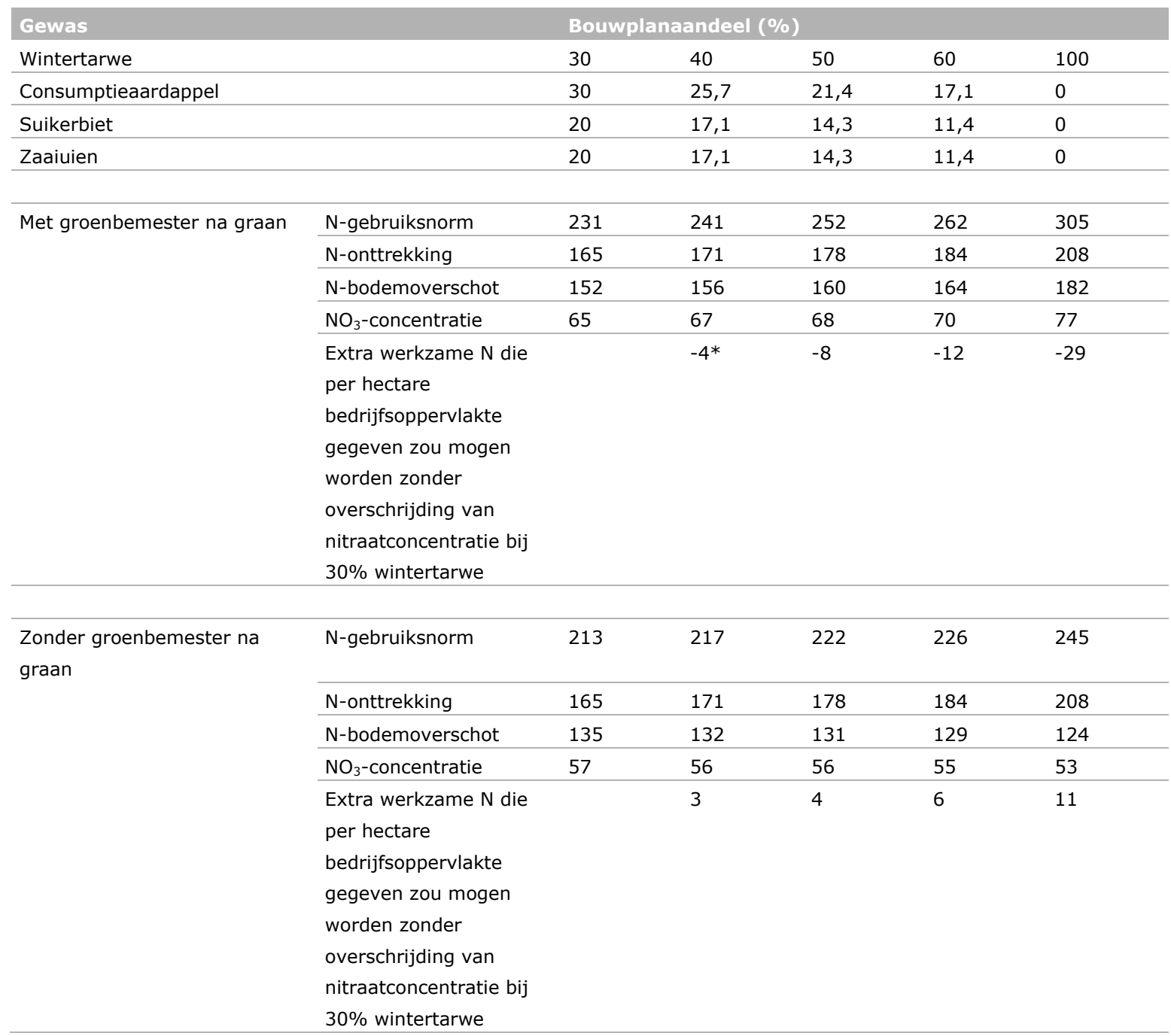

** Uitleg als voorbeeld: in dit specifieke geval (uitbreiding graanaandeel van $30 \%$ naar $40 \%$ en de teelt van een groenbemester na graan) ontstaat een verminderde $\mathrm{N}$ ruimte van $4 \mathrm{~kg} \mathrm{~N}$ per hectare bedrijfsoppervlakte onder de wettelijke norm van, in deze kolom, $241 \mathrm{~kg} N$ per hectare, teneinde de nitraatconcentratie niet te overschrijden die zou optreden bij graanaandeel van 30\% (te weten 65 mg nitraat/l voor de situatie met groenbemester na graan) 
Tabel $2 \boldsymbol{b} \quad$ Noordelijke Zandgrond: effect van hoger graanaandeel op N-gebruiksnorm, $N$ onttrekking, $\mathrm{N}$-bodemoverschot, $\mathrm{NO}_{3}$-concentratie van bovenste grondwater ( $\mathrm{mg} \mathrm{NO}_{3}$ per liter) en de extra of verminderde $\mathrm{N}$-ruimte in functie van het aandeel graan.

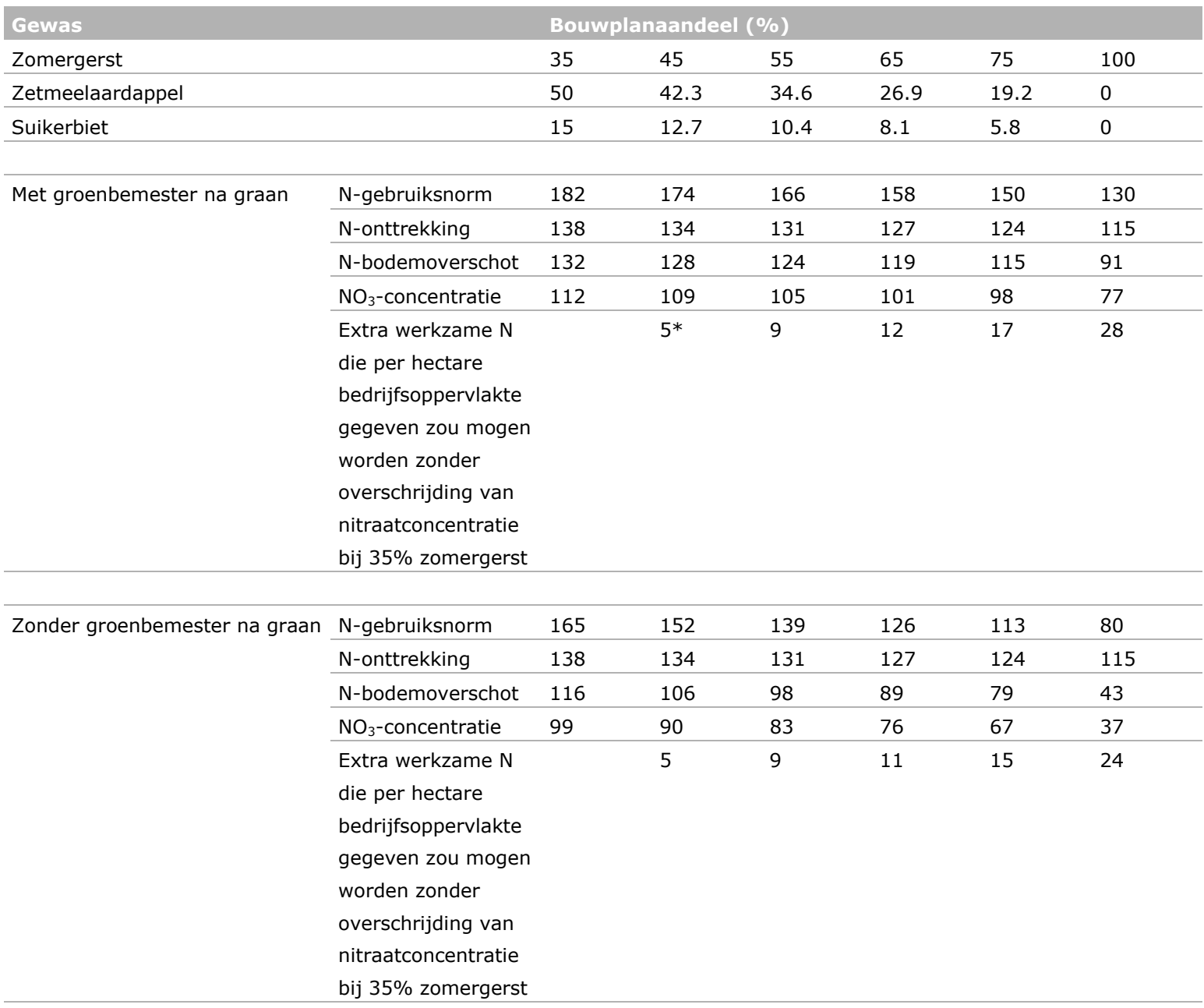

* Uitleg als voorbeeld: in dit specifieke geval (uitbreiding graanaandeel van $35 \%$ naar $45 \%$ en de teelt van een groenbemester na graan) ontstaat een extra $\mathrm{N}$ ruimte van $5 \mathrm{~kg} \mathrm{~N}$ per hectare bedrijfsoppervlakte boven op de wettelijke norm van, in deze kolom, $174 \mathrm{~kg} \mathrm{~N}$ per hectare, zonder dat de nitraatconcentratie te overschrijden die zou optreden bij graanaandeel van 35\% (te weten $112 \mathrm{mg}$ nitraat/l voor situatie met groenbemester na graan) 
Tabel 2c Zuidelijke Zandgrond: effect van hoger graanaandeel op N-gebruiksnorm, $N$-onttrekking, $\mathrm{N}$-bodemoverschot, $\mathrm{NO}_{3}$-concentratie van bovenste grondwater ( $\mathrm{mg} \mathrm{NO} \mathrm{NO}_{3}$ per liter) en de extra of verminderde $\mathrm{N}$-ruimte in functie van het aandeel graan.

\begin{tabular}{|c|c|c|c|c|c|c|}
\hline \multirow{2}{*}{$\begin{array}{l}\text { Gewas } \\
\text { Zomergerst }\end{array}$} & & \multicolumn{5}{|c|}{ Bouwplanaandeel (\%) } \\
\hline & & 30 & 40 & 50 & 60 & 100 \\
\hline Snijmaïs & & 25 & 21.4 & 17.9 & 14.3 & 0 \\
\hline Consumptieaardappel & & 30 & 25.7 & 21.4 & 17.1 & 0 \\
\hline Suikerbiet & & 15 & 12.9 & 10.7 & 8.6 & 0 \\
\hline \multirow[t]{5}{*}{ Met groenbemester na graan } & $\mathrm{N}$-gebruiksnorm & 141 & 139 & 138 & 136 & 130 \\
\hline & $\mathrm{N}$-onttrekking & 159 & 153 & 146 & 140 & 115 \\
\hline & $\mathrm{N}$-bodemoverschot & 70 & 74 & 79 & 84 & 104 \\
\hline & $\mathrm{NO}_{3}$-concentratie & 61 & 64 & 68 & 73 & 90 \\
\hline & $\begin{array}{l}\text { Extra werkzame } \mathrm{N} \\
\text { die per hectare } \\
\text { bedrijfsoppervlakte } \\
\text { gegeven zou mogen } \\
\text { worden zonder } \\
\text { overschrijding van } \\
\text { nitraatconcentratie } \\
\text { bij } 30 \% \text { zomergerst }\end{array}$ & & $-4 *$ & -9 & -14 & -33 \\
\hline \multirow[t]{5}{*}{ Zonder groenbemester na graan } & N-gebruiksnorm & 126 & 119 & 113 & 106 & 80 \\
\hline & $\mathrm{N}$-onttrekking & 159 & 153 & 146 & 140 & 115 \\
\hline & $\mathrm{N}$-bodemoverschot & 56 & 55 & 55 & 55 & 43 \\
\hline & $\mathrm{NO}_{3}$-concentratie & 48 & 48 & 48 & 48 & 37 \\
\hline & $\begin{array}{l}\text { Extra werkzame } \mathrm{N} \\
\text { die per hectare } \\
\text { bedrijfsoppervlakte } \\
\text { gegeven zou mogen } \\
\text { worden zonder } \\
\text { overschrijding van } \\
\text { nitraatconcentratie } \\
\text { bij } 30 \% \text { zomergerst }\end{array}$ & & 1 & 1 & 1 & 12 \\
\hline
\end{tabular}




\subsection{Afvoer van gewasresten}

De afvoer van gewasresten leidt tot een lager $\mathrm{N}$-bodemoverschot. Het effect is groter naarmate het bouwplan meer gewassen met $\mathrm{N}$-rijke gewasresten bevat die normaliter op het land zouden achterblijven. Het bouwplan met alleen prei en broccoli (bouwplan D) is hiervan een extreem voorbeeld. Als de milieuwinst als gevolg van de afvoer van gewasresten volledig zou worden omgezet in extra gebruiksruimte in het kader van een 'equivalente maatregel', dan zou in bouwplannen A, B, C en $D$, respectievelijk, 26, 25, 31 en 74 kg meer $N$ per hectare bedrijfsoppervlakte kunnen worden toegediend (Tabel 4). Als de gewasresten na opslag en eventuele verwerking (b.v. door vergisting en/of compostering) na de winter weer terug op het land zouden worden gebracht, wordt dit effect deels weer teniet gedaan (zie discussie).

Tabel 3 Effect van afvoer van gewasresten op nitraatconcentratie en de extra $\mathrm{N}$-ruimte die gegeven zou kunnen worden bij afvoer van gewasresten zonder de nitraatconcentratie van de referentie ('geen afvoer van gewasresten') te overschrijden.

\begin{tabular}{|c|c|c|c|c|c|c|c|c|c|c|c|c|}
\hline \multirow[b]{3}{*}{$\begin{array}{l}\text { Gewasrestafvoer } \\
\text { van: }\end{array}$} & \multicolumn{12}{|c|}{ Bouwplan: } \\
\hline & \multicolumn{3}{|l|}{$\mathbf{A}$} & \multicolumn{3}{|l|}{ B } & \multicolumn{3}{|l|}{ C } & \multicolumn{3}{|l|}{ D } \\
\hline & Geen & $\begin{array}{l}\text { Gerstestro, } \\
\text { bietenblad }\end{array}$ & & Geen & $\begin{array}{l}\text { Erwtenloof, } \\
\text { bietenblad }\end{array}$ & & Geen & Preiloof & & Geen & $\begin{array}{l}\text { Preiloof, } \\
\text { broccolistronk }\end{array}$ & \\
\hline $\begin{array}{l}\text { Gebruiksnorm, kg } \\
\text { N/ha }\end{array}$ & 166 & 166 & 192 & 125 & 125 & 150 & 156 & 156 & 187 & 184 & 184 & 258 \\
\hline Afvoer, kg N/ha & 132 & 158 & 158 & 140 & 165 & 165 & 100 & 130 & 130 & 99 & 173 & 173 \\
\hline $\begin{array}{l}\text { Bodemoverschot, } \\
\text { kg N/ha }\end{array}$ & 123 & 97 & 123 & 86 & 61 & 86 & 147 & 116 & 147 & 172 & 98 & 172 \\
\hline $\begin{array}{l}\text { Nitraatconcentratie, } \\
\mathrm{mg} \mathrm{NO}_{3} / \mathrm{l}\end{array}$ & 104 & 82 & 104 & 74 & 53 & 74 & 127 & 100 & 127 & 149 & 85 & 149 \\
\hline
\end{tabular}




\subsection{Meer groenbemesters en vanggewassen}

In paragrafen 2.1 en 3.1 is uitgelegd en uitgewerkt waarom de teelt van bemeste groenbemester binnen een $\mathrm{N}$-concentratie-doelstelling meestal niet leidt tot meer bemestingsruimte dan thans wettelijk is toegestaan. Deze paragraaf 3.3 beperkt zich daarom tot het effect van de teelt van meer onbemeste groenbemesters, ook wel vanggewassen genoemd.

Uit de berekeningen blijkt dat de teelt van vanggewassen het gebruik van werkzame $\mathrm{N}$ kan helpen verhogen zonder de nitraatconcentratie te verhogen als gevolg van hogere opbrengsten: het leidt tot een hogere $\mathrm{N}$-onttrekking en een lager bodemoverschot. De berekeningen geven echter ook aan dat dit effect meer dan wegvalt (en zelfs een verlaging van $\mathrm{N}$ giften nodig maakt) naarmate meer rekening gehouden moet worden met een verlaging van de $\mathrm{N}$-onttrekking van het voorafgaande hoofdgewas als het voor een succesvolle teelt van het vanggewas nodig is dat hoofdgewas eerder te oogsten (zie 2.3.2 voor de werkwijze en Tabel 4 voor het resultaat).

Tabel 4 Effect van de teelt van vanggewassen (in aanvulling op reeds verplichte teelt na snijmaïs in bouwplan B) op de berekende $\mathrm{N}$-onttrekking op bedrijfsniveau, het $\mathrm{N}$-bodemoverschot en de $\mathrm{NO}_{3}{ }^{-}$ concentratie, en verandering van $N$-ruimte op bedrijfsniveau, in afhankelijkheid van de teelt van een vanggewas met en zonder een verlaging met $10 \%$ van de $\mathrm{N}$-onttrekking van het hoofdgewas ten behoeve van een tijdige oogst.

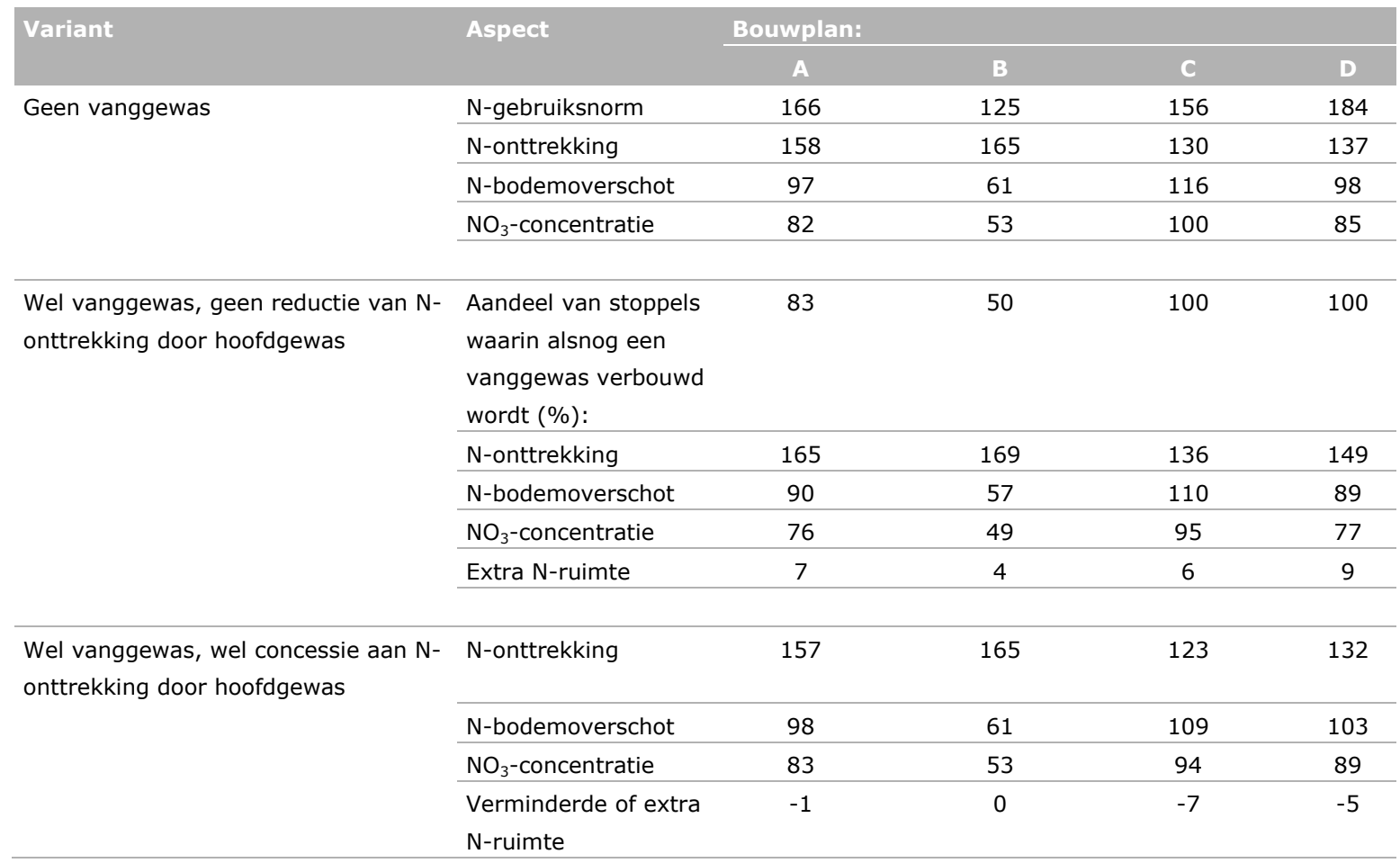


Bij de onderbouwing van de $\mathrm{N}$-gebruiksnormen voor snijmaïs is indertijd uitgegaan van een oogsttijdstip van maïs (en start van (her)groei van vanggewas) tussen 10 en 20 september. Daarbij realiseert het vanggewas een $\mathrm{N}$-onttrekking van ongeveer $40 \mathrm{~kg} \mathrm{~N}$ per hectare. Tabel 5 laat zien dat een eerdere ( 1 september) of latere oogstdatum (30 september) niet tot een verdere verlaging van de nitraatconcentratie leidt via een verlaagd $\mathrm{N}$-bodemoverschot en een verhoogde onttrekking door het hoofdgewas: bij vroege oogst daalt de N-onttrekking van het hoofdgewas sterker dan dat die van het vanggewas toeneemt. Later oogsten dan 20 september leidt niet of nauwelijks tot een hogere $\mathrm{N}$-onttrekking, terwijl de kans op een hogere $\mathrm{N}$-onderschepping door een vanggewas wel sterk afneemt. Naarmate de wettelijk toegestane $\mathrm{N}$-voorziening lager is (Zuidelijke Zand- en Lössgronden) heeft dat een negatief effect op een volgend maïsgewas. Een extra vroege maïsoogst verbetert de groeikansen van een vanggewas sterk (en daarmee de $\mathrm{N}$-voorziening van een volgend maïsgewas) maar gaat anderzijds ten koste van de lengte van het groeiseizoen voor mais en, ten gevolge daarvan, ten koste van de $\mathrm{N}$-onttrekking van de maïs. Oogsten tussen 10 en 20 september lijkt het beste compromis tussen beide.

Tabel 5 Berekende effecten van oogstdatum van continue snijmaïs ofwel (her)groei datum van vanggewas op de $\mathrm{N}$-onttrekking van maïs en vanggewas ( $\mathrm{kg} \mathrm{N} / \mathrm{ha}$ ) en nitraatconcentratie $\left(\mathrm{mg} \mathrm{NO}_{3} / \mathrm{I}\right)$ van het bovenste grondwater onder een matig droge zandgrond in Zuid Nederland ( $N$-gebruiksnorm $112 \mathrm{~kg} \mathrm{~N} / \mathrm{ha}$ ) en op matig droge zandgrond elders in Nederland ( $\mathrm{N}$-gebruiksnorm $140 \mathrm{~kg} \mathrm{~N} / \mathrm{ha}$ ).

\begin{tabular}{|c|c|c|c|c|c|c|}
\hline Oogstdatum & Regio & \multicolumn{5}{|l|}{ Aspect: } \\
\hline \multirow{3}{*}{ Regio } & \multirow{3}{*}{ Oogstdatum } & \multicolumn{3}{|c|}{ N-onttrekking } & \multicolumn{2}{|c|}{$\begin{array}{l}\mathrm{NO}_{3}^{-} \\
\text {concentratie }\end{array}$} \\
\hline & & \multirow{2}{*}{$\begin{array}{l}\text { Geen } \\
\text { vanggewas } \\
\text { Maïs }\end{array}$} & \multicolumn{2}{|c|}{$\begin{array}{l}\text { Wel } \\
\text { vanggewas }\end{array}$} & \multirow{2}{*}{$\begin{array}{l}\text { Geen } \\
\text { vangs }\end{array}$} & \multirow{2}{*}{ Wel vanggewas } \\
\hline & & & Maïs & Vanggewas & & \\
\hline \multirow{3}{*}{$\begin{array}{l}\text { Zuid } \\
\text { Nederland }\end{array}$} & 10 sept. & 150 & 162 & 48 & 60 & 50 \\
\hline & 20 sept. & 153 & 162 & 34 & 58 & 51 \\
\hline & 30 sept. & 153 & 159 & 20 & 57 & 53 \\
\hline $\begin{array}{l}\text { Elders in } \\
\text { Nederland }\end{array}$ & 30 sept. & 165 & 170 & 20 & 69 & 66 \\
\hline
\end{tabular}




\section{Discussie}

Een onderbouwing voor de verruiming van $\mathrm{N}$-gebruiksnormen in het kader van 'equivalente maatregelen' is om diverse redenen lastig. Dit is in de eerste plaats zo omdat aangetoond moet kunnen worden dat de maatregel (handeling, omstandigheid, realisatie) zich onderscheidt van het geheel van maatregelen waarvan is uitgegaan bij de onderbouwing van de generieke $\mathrm{N}$-gebruiksnormen en/of $\mathrm{N}$-bodemoverschot dan wel de $\mathrm{N}$-belasting van ontvangende wateren (grondwater, oppervlaktewater) in de periode voorafgaand aan de invoering van de equivalente maatregel. Vanuit die optiek lijkt de realisatie van hogere opbrengsten dan de gemiddelde opbrengst waarvan bij de onderbouwing is uitgegaan, voldoende grond voor erkenning van een equivalente maatregel i.e. de toekenning van extra N-ruimte. Daarbij kan alleen dan aan de eis van een 'minimaal even goed milieuresultaat' worden voldaan als degene die beneden-gemiddelde opbrengsten realiseert een korting op de $\mathrm{N}$-ruimte krijgt.

Voor zover equivalente maatregelen gebaseerd zijn op maatregelen die beogen de beschikbaarheid van toegediende $\mathrm{N}$ te vergroten (betere plaatsing, betere timing, onderscheppen en doorgeven van $\mathrm{N}$-residuen aan volgteelten met behulp van vanggewassen), geldt bovendien dat dergelijke maatregelen alleen dan het $\mathrm{N}$-bodemoverschot verlagen zolang gewassen positief op $\mathrm{N}$ reageren. De kans hierop neemt toe in de volgorde kleigrond<overige zandgrond<zandgrond en loessgrond in Zuid Nederland. Dat is een gevolg van het feit dat de N-gebruiksnormen in die volgorde sterker beneden landbouwkundig geadviseerde $\mathrm{N}$-giften liggen. Ook deze factor maakt het lastig om equivalente maatregelen gelijktijdig voor heel Nederland te kunnen onderbouwen.

Een complicerende factor voor een onderbouwing van equivalente maatregelen is wellicht het feit dat onderbouwingen op modelmatige schattingen van effecten van gecombineerde maatregelen gebaseerd zijn, terwijl die combinatie van maatregelen niet experimenteel getoetst is. Weliswaar zijn die modellen gebaseerd op afzonderlijke proeven die ooit hebben plaatsgevonden, maar modellen gaan voor een belangrijk deel voorbij aan de spreidingen en interacties die in de praktijk zullen optreden. Daarbij valt te denken aan de wisselwerkingen tussen opbrengstniveaus van gewassen en $\mathrm{N}$-gehalten, de invloed van de bouwplansamenstelling en het gebruik van organische meststoffen op opbrengsten en het lot van bodemoverschot, en de aard en omvang van $\mathrm{N}$-bodemoverschotten op de uiteindelijke uit- en afspoeling van $\mathrm{N}$. Het groeiende gebrek aan actuele experimentele toetsingen, maakt het nodig om de hier gepresenteerde berekeningen ook daarom met voorzichtigheid te hanteren.

De hier gebruikte modellen gaan uit van een evenwichtssituatie. Dat betekent dat de becijferde opbrengsten en onttrekkingen bij (lage) N-gebruiksnormen niet geflatteerd worden doordat geprofiteerd wordt van $\mathrm{N}$-levering vanuit een verleden waarin van N-gebruiksnormen nog geen sprake was. Anderzijds houden de modellen geen rekening met het effect dat eventuele tekorten aan organische stof en fosfaat op termijn ook op de N-benutting en -onttrekking kunnen hebben. De recente Evaluatie Meststoffenwet (EMW, 2017) geeft overigens geen aanwijzingen dat organische stof en fosfaat zich op grote schaal beneden niveaus bevinden die opbrengst-beperkend zouden zijn geworden onder invloed van aanscherpende wetgeving. Hierbij moet wel bedacht worden dat een equivalente maatregel zoals de afvoer van gewasresten tot een verdere vermindering van de aanvoer van organische stof zal leiden. Een oplossing hiervoor is gelegen in het verliesarm bewaren en/of verwerken van deze gewasresten teneinde ze na de winter als organische meststof te gebruiken. De winst die de afvoer van gewasresten kan opleveren in de vorm van een verhoogde N-gebruiksnorm, wordt dan wel op zijn minst deels weer teniet gedaan omdat organische meststoffen vanwege mineralisatie buiten het groeiseizoen weer een korting op de N-gebruiksnorm nodig maken.

In aanvulling op de (wettelijk verplichte) teelt van een vanggewas na maïs op zand- en loessgrond, zou een dergelijke teelt na meer gewassen plaats kunnen vinden. De berekeningen geven aan dat dat een gunstig effect op de $\mathrm{N}$-uitspoeling kan hebben en aldus, onder omstandigheden, een verruiming van de $\mathrm{N}$-gebruiksnorm kan helpen onderbouwen. Bij die berekening is alleen uitgegaan van de 
bijdrage die vanggewassen hebben bij het onderscheppen en 'over de winter heen tillen' van $\mathrm{N}$ en nog niet van het mogelijk gunstige effect dat vanggewassen kunnen hebben bij het bevorderen van denitrificatie, vergelijkbaar met grasland. Hiervoor zou aanvullend experimenteel onderzoek nodig zijn.

Ten slotte moet worden opgemerkt dat equivalente maatregelen doorgaans kosten met zich mee zullen brengen. Daarmee betalen equivalente maatregelen zich niet per definitie terug. De becijfering van de effecten op de kosten en baten viel echter buiten de opdracht van deze studie. 


\section{Literatuur}

De Ruijter, F.J., J.J. Schröder, W.C.A. van Geel \& R. Postma, 2017. Beoordeling van mogelijk gebruik van $\mathrm{N}$ bijbemestsystemen voor aardappelen als equivalente maatregel. Rapport 672, Wageningen UR/NMI/BO Akkerbouw, Wageningen, $37 \mathrm{pp}$.

EMW, 2017. Evaluatie Meststoffenwet 2016: syntheserapport. Planbureau voor de Leefomgeving, Publicatie 2258, Den Haag, 191 pp.

Groenendijk, P., L Renaud, O. Schoumans, J.J. Schröder, T. de Koeijer, H. Luesink, 2014. Vergelijking van het WOG-WOD model en het MAMBO-STONE model, Rapport 2549, Alterra, WUR, 54 pp.

Groenendijk, P., E.M.P.M. van Boekel, L. Renaud, A. Greijdanus, R. Michels \& T. de Koeijer, 2016. Landbouw en de KRW-opgave voor nutriënten in regionale wateren : het aandeel van landbouw in de KRW-opgave, de kosten van enkele maatregelen en de effecten ervan op de uit- en afspoeling uit landbouwgronden. Rapport 2749, Wageningen Environmental Research (WUR), Wageningen, $149 \mathrm{pp}$.

Min EZ, 2013. Vijfde Nederlandse Actieprogramma betreffende de Nitraatrichtlijn (2014-2017). Ministerie van Economische Zaken, 's-Gravenhage, $88 \mathrm{pp}$.

Noij, G.J., W. Corre, E.M.P.M. Boekel, H.P. Oosterom, J.C. van Middelkoop, W. van Dijk, O.A. Clevering, L.V. Renaud \& P.J.T. van Bakel, 2008. Kosteneffectiviteit van alternatieve maatregelen voor bufferstroken in Nederland. Publication series 6, Alterra (WUR), Wageningen, $227 \mathrm{pp}$.

Noij, I.G.A.M., C. van der Salm, H.T.L. Massop, E.M.P.M. Boekel, C. Schuiling, M. Pleijter, O.A. Clevering, P.J.T. van Bakel, W.J. Chardon \& D.J.J. Walvoort, 2009. Beleidskader fosfaat voor Noord- en Midden-Limburg : wetenschappelijke onderbouwing. Rapport 1894, Alterra (WUR), Wageningen, $144 \mathrm{pp}$.

Os, E.A. van, I.G.A.M., Noij, P.J.T. van Bakel, W.P. de Winter \& F.J.E. van der Bolt, 2009. Kennissysteem voor het bepalen van effecten van brongerichte maatregelen op de uitspoeling van $\mathrm{N}$ en $\mathrm{P}$ naar grond- en oppervlaktewater : bijdrage maatregelen WB21 aan de realisatie van de KRW. Rapport 1863, Alterra (WUR), Wageningen, 50 pp.

Schoumans, O.F., J.J. de Haan, F.J. de Ruijter, F.J.E. van der Bolt, O. Oenema, E.M.P.M. van Boekel \& J.R. van der Schoot, 2012. Analyse maatregelen om nutriëntenemissies uit de landbouw te verminderen : deskstudie ter voorbereiding van plan-MER. Rapport 2385, Alterra (WUR), Wageningen, $90 \mathrm{pp}$.

Schröder, J.J., 2016. Effect van geactualiseerde invoergegevens op de berekende nitraatconcentratie in ondiep grondwater onder landbouwbedrijven op zandgrond. Notitie in opdracht van Ministerie EZ, Wageningen UR, Wageningen, $16 \mathrm{pp}$.

Schröder, J.J. \& J.J. de Haan, 2015. Equivalente maatregelen in de akkerbouw: verkenning naar de effecten van huidige opbrengstniveaus en van een terughoudend gebruik van dierlijke mest op de toelaatbare hoogte van N-gebruiksnormen te verhogen. Notitie in opdracht van LTO, Wageningen UR, Wageningen, $12 \mathrm{pp}$.

Schröder, J.J. \& W. van Dijk, 2017. Actualisatie van stikstof-, fosfaat en organische stof balansen van akkerbouw- en vollegrondsgroentenbedrijven. Rapport in opdracht van Brancheorganisatie Akkerbouw (BOA), Wageningen UR, Wageningen, 25 pp. 
Schröder, J.J., J.J. de Haan \& J.R. van der Schoot, 2015a. Meststofgebruiksruimte in relatie tot opbrengstniveaus, mestsoort en rijenbemesting. Rapport 638, PPO-AGV, Wageningen UR, Lelystad, $44 \mathrm{pp}$.

Schröder, J.J., C.H.G. Daatselaar, T.J. de Koeijer \& J.J. de Haan, 2015b. Opbrengstafhankelijke Ngebruiksnormen. Notitie in opdracht van Ministerie EZ, Wageningen UR, Wageningen, 21 pp.

Stuyt, L.C.P.M., P.J.T. van Bakel, W. van Dijk, W.J.M. de Groot, J. van Kleef, I.G.A.M. Noij, J.R. van der Schoot, A. van den Toorn \& R. Visschers, 2009. Samengestelde, peilgestuurde drainage in Nederland : voortgangsrapport 1. Rapport, Alterra (WUR), Wageningen, $151 \mathrm{pp}$.

Van Dijk, W., 2003. Adviesbasis voor de bemesting van akkerbouw- en vollegrondsgroentengewassen. PPO-publicatie nr. 307, Praktijkonderzoek Plant \& Omgeving, Lelystad, 66 pp.

Verhoeven, J., K. Bus, W. van Dijk, W. van Geel, H. van Schooten, J.J. Schröder \& R. Wustman, 2010. Teeltvervroeging bij consumptieaardappel en snijmaïs op zand ten behoeve van vanggewassen: deskstudie naar mogelijkheden en beperkingen. Rapport 32501730 10, PPO-AGV, Lelystad, $67 \mathrm{pp}$. 
Correspondentie adres voor dit rapport: Postbus 16

6700 AA Wageningen

T 0317480700

www.wur.nl/plant-research

Rapport 682
De missie van Wageningen University \& Research is 'To explore the potential of nature to improve the quality of life'. Binnen Wageningen University \& Research bundelen Wageningen University en gespecialiseerde onderzoeksinstituten van Stichting Wageningen Research hun krachten om bij te dragen aan de oplossing van belangrijke vragen in het domein van gezonde voeding en leefomgeving. Met ongeveer 30 vestigingen, 5.000 medewerkers en 10.000 studenten behoort Wageningen University \& Research wereldwijd tot de aansprekende kennisinstellingen binnen haar domein. De integrale benadering van de vraagstukken en de samenwerking tussen verschillende disciplines vormen het hart van de unieke Wageningen aanpak. 



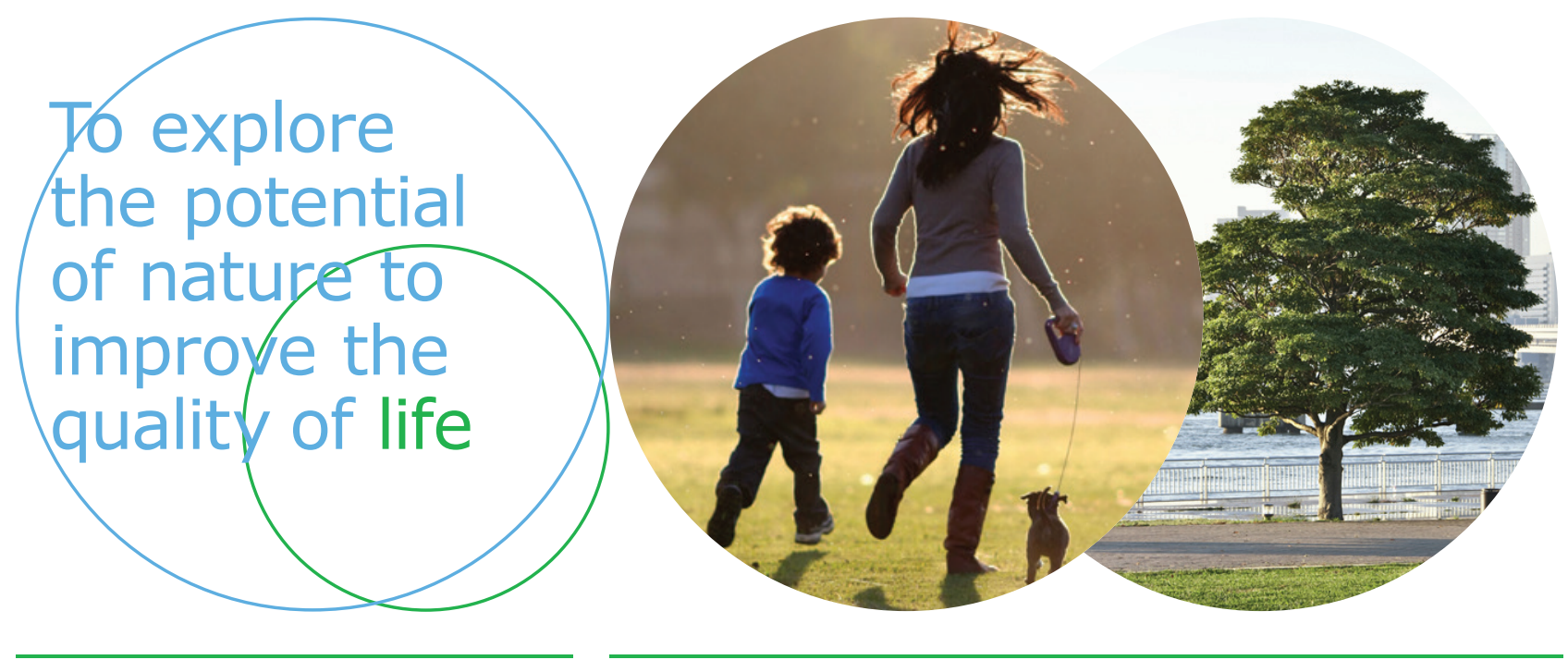

Correspondentie adres voor dit rapport: Postbus 16

6700 AA Wageningen

T 0317480700

www.wur.nl/plant-research

Rapport 682
De missie van Wageningen University \& Research is 'To explore the potential of nature to improve the quality of life'. Binnen Wageningen University \& Research bundelen Wageningen University en gespecialiseerde onderzoeksinstituten van Stichting Wageningen Research hun krachten om bij te dragen aan de oplossing van belangrijke vragen in het domein van gezonde voeding en leefomgeving. Met ongeveer 30 vestigingen, 5.000 medewerkers en 10.000 studenten behoort Wageningen University \& Research wereldwijd tot de aansprekende kennisinstellingen binnen haar domein. De integrale benadering van de vraagstukken en de samenwerking tussen verschillende disciplines vormen het hart van de unieke Wageningen aanpak. 